\title{
Mercury in bats from the northeastern United States
}

\author{
David E. Yates $\cdot$ Evan M. Adams $\cdot$ Sofia E. Angelo $\cdot$ David C. Evers $\cdot$ \\ John Schmerfeld • Marianne S. Moore • Thomas H. Kunz • Timothy Divoll • \\ Samuel T. Edmonds $\cdot$ Christopher Perkins $\cdot$ Robert Taylor $\cdot$ Nelson J. O'Driscoll
}

Accepted: 30 October 2013/Published online: 23 November 2013

(C) The Author(s) 2013. This article is published with open access at Springerlink.com

\begin{abstract}
This study examines mercury exposure in bats across the northeast U.S. from 2005 to 2009 . We collected 1,481 fur and 681 blood samples from 8 states and analyzed them for total $\mathrm{Hg}$. A subset $(n=20)$ are also analyzed for methylmercury (MeHg). Ten species of bats from the northeast U.S. are represented in this study of which two are protected by the Endangered Species Act (ESA 1973) and two other species are pending review. There are four objectives in this paper: (1) to examine correlates to differences in fur-Hg levels among all of the sampling sites, including age, sex, species, and presence of a $\mathrm{Hg}$ point source; (2) define the relationship between blood and fur-Hg levels and the factors that influence that
\end{abstract}

D. E. Yates $(\bowtie) \cdot$ E. M. Adams · S. E. Angelo ·

D. C. Evers · T. Divoll · S. T. Edmonds

BioDiversity Research Institute, 19 Flaggy Meadow Road,

Gorham, ME 04038, USA

e-mail: dave.yates@briloon.org

J. Schmerfeld

U.S. Fish and Wildlife Service, Virginia Field Office, 6669 Short

Lane, Gloucester, VA 23061, USA

M. S. Moore · T. H. Kunz

Center for Ecology and Conservation Biology, Boston

University, 5 Cummington Street, Boston, MA 02215, USA

S. T. Edmonds · N. J. O’Driscoll

K.C. Irving Environmental Science Centre, 32 University Ave,

Wolfville, NS B4P 2R6, Canada

C. Perkins

University of Connecticut, 3107 Horse Barn Hill Rd. \# U-4210,

Storrs Mansfield, CT 06269, USA

R. Taylor

Trace Element Research Laboratory, Highway 60 VMA

Building, College Station, TX 77843, USA relationship including age, sex, species, reproductive status, and energetic condition; (3) determine the relationships between total $\mathrm{Hg}$ and $\mathrm{MeHg}$ in five common eastern bat species; and (4) assess the distribution of $\mathrm{Hg}$ across bat populations in the northeast. We found total blood and fur mercury was eight times higher in bats captured near point sources compared to nonpoint sources. Blood- $\mathrm{Hg}$ and fur$\mathrm{Hg}$ were well correlated with females on average accumulating two times more $\mathrm{Hg}$ in fur than males. On average fur $\mathrm{MeHg}$ accounted for $86 \%$ (range 71-95\%) of the total $\mathrm{Hg}$ in bat fur. Considering that females had high $\mathrm{Hg}$ concentrations, beyond that of established levels of concern, suggests there could be negative implications for bat populations from high $\mathrm{Hg}$ exposure since $\mathrm{Hg}$ is readily transferred to pups via breast milk. Bats provide an integral part of the ecosystem and their protection is considered to be of high priority. More research is needed to determine if $\mathrm{Hg}$ is a stressor that is negatively impacting bat populations.

Keywords Mercury $\cdot \mathrm{Hg} \cdot$ Methylmercury $\cdot \mathrm{MeHg}$. Bats $\cdot$ Northeast United States

\section{Introduction}

Mercury $(\mathrm{Hg})$ in surface waters throughout the northeastern United States occur at relatively high concentrations and is released into the atmosphere in large part to due anthropogenic activities such as fossil fuel combustion, garbage incineration, gold mining, chlor-alkali, and textile manufacturing (Chen et al. 2005; Driscoll et al. 2007; Evers et al. 2007), while natural sources of atmospheric mercury provide a minor share (Schuster et al. 2002; Pirrone et al. 2010). Atmospheric deposition and waterborne point sources of $\mathrm{Hg}$, in combination with environmental 
conditions that promote $\mathrm{Hg}$-methylation and bioavailability, have led to the identification of several $\mathrm{Hg}$ hotspots in the Northeast (Chen et al. 2005; Evers et al. 2007). Forested regions may be particularly susceptible to high $\mathrm{Hg}$ levels owing to the filtering properties of the canopy and presence of wetlands that facilitate the bacterial transformation of $\mathrm{Hg}$ into methylmercury ( $\mathrm{MeHg}$ ) - a more biologically and ecologically relevant form (Driscoll et al. 2007). Numerous studies have reported on the distribution of $\mathrm{Hg}$ and $\mathrm{MeHg}$ in the United States (US), particularly in the northeastern region (Chasar et al. 2009; Evers and Clair 2005; Ward et al. 2010). Evers et al. (2007) identified five biological $\mathrm{Hg}$ hotspots in the northeastern United States (Maine, Massachusetts, Vermont, New Hampshire, New York) and one in southeastern Canada (Nova Scotia). In an effort to better understand the full-extent of the threat of $\mathrm{Hg}$ to wildlife in the Northeast, we evaluated bats as indicators of $\mathrm{Hg}$ bioavailability in terrestrial ecosystems.

Bats are excellent $\mathrm{Hg}$ bioindicators as: (1) many bat species are distributed across wide geographic ranges and while individuals of several species live in habitats that are relatively pristine, other individuals of the same species live near heavily industrialized areas or point sources of $\mathrm{Hg}$ emission; (2) most bat species are relatively long-lived (Brunet-Rossini 2004; Brunet-Rossini and Austed 2004; Wilkinson and South 2002; Kunz and Lumsden 2003) and so $\mathrm{Hg}$ may accumulate with age; (3) many bats of the Northeast are at high trophic levels making them susceptible to biomagnification (O'Shea and Johnson 2009; O'Shea et al. 2001); (4) bats may be exposed to higher Hg loads compared to other animals of similar size due to their high metabolic rate and food intake (Kunz 2004; Kunz et al. 1995; Kurta et al. 1989, Hickey et al. 2001; Wada et al. 2010). Mercury may also be of particular harm to bat populations as they have lower reproductive output compared with many other traditional study species, requiring adult survival for population stability (Barclay and Harder 2003; O'Shea and Johnson 2009). Additionally, bats are frequently subjected to multiple anthropogenic stressors and a number of species are endangered or threatened with extinction (Mickleburgh et al. 2002), or are experiencing rapid population loss.

While a large number of studies have explored $\mathrm{Hg}$ exposure to bats (Baron et al. 1999; Brooks and Ford 2005; Hickey et al. 2001; Miura et al. 1978; O'Shea et al. 2001; Petit and Altenbach 1973; Powell 1983; Wada et al. 2010; Walker et al. 2007), a knowledge gap remains with respect to spatial and temporal patterns of exposure and possible physiological effects. Blood and fur collected from bats at an anthropogenic Hg point source on South River, VA and a nearby reference site was analyzed by Wada et al. (2010). They found that mean concentrations of $\mathrm{Hg}$ in blood were significantly higher at the point source compared to a reference site. The mean value of $\mathrm{Hg}$ in bat fur $[28.0 \mu \mathrm{g} / \mathrm{g}$, fresh weight (fw)] was among the highest detected in wild mammals, and similar to other published mean values reported for bats captured at other point sources. The tri-colored bat, Perimyotis subflavus, which feeds over the North Fork of the Holston River in Virginia, a Hg point source, had significantly higher $\mathrm{Hg}$ concentrations in liver and muscle tissues compared to a control site (Powell 1983). Aquatic nymphs of flying insects from this river also had elevated $\mathrm{Hg}$ compared to areas upstream from the source (Powell 1983). Bat fur-Hg concentrations have been documented to exceed $30 \mu \mathrm{g} / \mathrm{g}$ for individuals sampled at areas with previously documented high $\mathrm{Hg}$ concentrations present in the environment (Miura et al. 1978; Grippo and Massa 2000).

This study examines $\mathrm{Hg}$ levels found in bats of the eastern United States. There are four objectives in this paper: (1) to examine correlates to differences in fur- $\mathrm{Hg}$ levels among all of the sampling sites, including age, sex, species, and presence of a $\mathrm{Hg}$ point source; (2) define the relationship between blood and fur- $\mathrm{Hg}$ levels and the factors that influence that relationship including age, sex, species, reproductive status, and energetic condition; (3) determine the relationships between total $\mathrm{Hg}$ and $\mathrm{MeHg}$ in five common eastern bat species; and (4) assess the distribution of $\mathrm{Hg}$ across bat populations in the northeast.

\section{Study area}

Fur and blood samples were taken from bats in Maine, Maryland, Massachusetts, Virginia, New Hampshire, Pennsylvania, New York, and West Virginia at 89 sites between 2005 and 2009 (Fig. 1). Samples were collected at 20 sites with known anthropogenic $\mathrm{Hg}$ point sources upstream on two rivers in Virginia-the South River (textile, mercuric sulfate) and the North Fork of the Holston (chlor-alkali, mercuric chloride)—and at 69 sites with no recorded anthropogenic $\mathrm{Hg}$ inputs. The 20 sites in VA were defined as point-source contaminated areas using the definition given by the U.S. Environmental Protection Agency; as any stationary location or fixed facility from which pollutants are discharged or emitted or any single, identifiable discharge point of pollution, such as a pipe, ditch, or smokestack (US EPA 2010). Locations without a known point source were considered to be sites of atmospheric deposition. Fur samples were collected and analyzed for all of the seven states, while blood was only analyzed for sites in Maine, New York and Virginia.

Capture, sample collection and handling

Bat capture, and fur and blood sampling were conducted between June and August in 2005-2009. Bats were captured using mistnets and harp traps (Constantine 1958) and also 
Fig. 1 Sites sampled across the Northeast for $\mathrm{Hg}$ in fur and blood from bats (2006-2009)

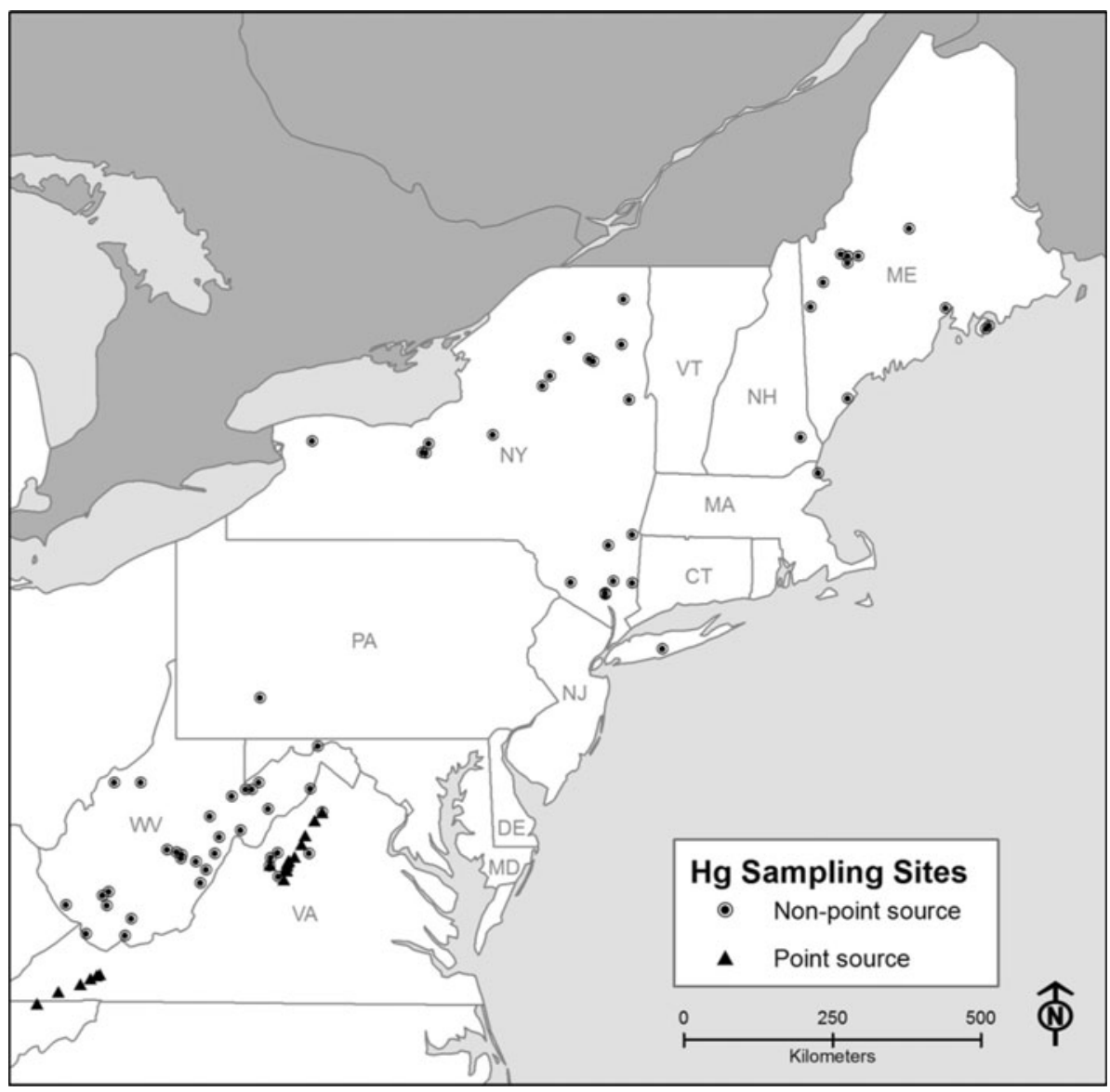

directly from roosts by hand. Beginning in 2007, USFWS white-nose syndrome decontaminant protocols were followed to prevent spread of Pseudogymnoascus destructans, the fungus believed to be responsible for high bat mortality rates in recent years (USFWS 2010). This protocol involved holding bats in single use disposable bags and disinfecting nets and equipment between trap sites (USFWS 2010).Fur samples were collected by trimming using stainless steel scissors that were cleaned and visually inspected between individuals to prevent cross contamination. Fur was stored in plastic zip bags $(2 \times 2$ in.). Blood samples were collected by puncturing the acute ulnar or uropatagium vein with a sterile 27.5 gauge needle, and collecting the pooled blood in heparinized capillary tubes. Capillary tubes were sealed with Crito-caps, placed in labeled vacutainer tubes, set on ice, and stored at $-20{ }^{\circ} \mathrm{C}$ until laboratory analysis. Individuals were then examined to determine age (Kunz and Anthony 1982) and sex, and measured [forearm length in millimeter $(\mathrm{mm})$ and weight in grams $(\mathrm{g})]$. All bats were released onsite following collection.

Mercury analysis

Total Hg concentrations were analyzed in sampled tissues. Fur-Hg was analyzed across all sites and for all years.
Blood $\mathrm{Hg}$ was analyzed from bats sampled in 2007-2008. Laboratory analysis of THg in blood and fur (2005-2009) was conducted at the University of Connecticut (Center for Environmental Science and Engineering, Storrs, CT, USA) and the Biodiversity Research Institute (Gorham, ME. Quality control methods (including the use of external certified reference materials DOLT-4 and DORM-3) were used at both laboratories to ensure consistent analytical precision and accuracy. Recovery of total-Hg for all sample batches ranged from 90 to $110 \%$. Fur samples were analyzed for total $\mathrm{Hg}$ using a thermal decomposition technique with a direct $\mathrm{Hg}$ analyzer (DMA 80, Milestone Incorporated) using US EPA Method 7473 (Lesnik and Fordman 1998). Blood samples were analyzed for total mercury using cold vapor atomic fluorescence spectrophotometry (CVAFS) by EPA method 1631. Blood Hg concentrations are presented as wet weight (ww) and fur-Hg concentrations are presented as fw. Detection limits (DLs) for all batches were lower than $2.5 \mathrm{ng} / \mathrm{g}$ and all samples well exceeded this lower threshold.

Blood samples were digested with nitric and sulfuric acids at $95{ }^{\circ} \mathrm{C}$ for $10 \mathrm{~min}$, oxidized with $0.02 \mathrm{~N}$ bromine monochloride, reduced with stannous chloride, bubbled onto a gold trap, and purged into a Brooks Rand Model III CVAFS for analysis. Sample mass for blood ranged from 0.006 to 
$0.02 \mathrm{~g}$ with an average detection limit of $0.01 \mathrm{ng} / \mathrm{g}$, ranging from 0.004 to $0.4 \mu \mathrm{g} / \mathrm{g}$, which were calculated according to standard EPA protocols. Standard quality assurance procedures were employed, including analysis of replicate samples [relative percent difference $(\mathrm{RPD})=17.0 \%$ ], method blanks (all below detection limit), spiked samples (percent recovery $=104.3 \%$ ), laboratory control samples (percent recovery $=106.0 \%$ ), quantitation limit samples, and standard reference material recovery (DOLT-3 $=95.0 \%$ and DORM-2 $=102.5 \%$, National Research Council, Canada; SRM $966=100.5 \%$, National Institute of Standards and Technology) the average RPD was $9.7 \%$. Instrument response was evaluated initially, every 20 samples, including quality control samples, and at the end of an analytical run using calibration verification standard and blank.

Methylmercury in fur was analyzed in subset of fur samples collected from one of the non-point source sites in VA to provide an approximation of the percentage of $\mathrm{MeHg}$ of the total-Hg in fur. Analysis for $\mathrm{Hg}$ species in fur was completed at Acadia University, Nova Scotia following digestion in $25 \% \mathrm{KOH} / \mathrm{MeOH}$, similar to methods described by Liang et al. (1994), Edmonds et al. (2010). Quality control included method replicates (mean $\mathrm{COV}=5 \%, 3 \% ; n=2$, [MeHg; THg]), analytical triplicate (mean $\mathrm{COV}=15 \%, 14 \% ; n=1$ ), method blanks $[\mathrm{DLs}=0.23 \mathrm{pg} \mathrm{MeHg} ; 0.46 \mathrm{pg} \mathrm{Hg}(\mathrm{II})]$, and certified reference material (DOLT-4, National Research Council, Canada, mean recovery $=101 \% \mathrm{MeHg}, 104 \% \mathrm{THg}$, $n=3)$.

\section{Statistical analysis}

For our objectives we chose to use linear mixed models to test specific hypotheses about the factors that influence fur$\mathrm{Hg}$ levels in bats across multiple sites and species, and the relationship between blood and fur- $\mathrm{Hg}$ levels at the few sites where both types of tissues were collected. For our analysis of $\mathrm{Hg}$ in fur across all sites, we tested the hypothesis that fur-Hg levels changed due to species, bat age, bat sex, and whether the site was in close proximity to a known $\mathrm{Hg}$ point source as all of these variables were collected in all the data sets. In this case, it made sense to make site and year random variables because sampling was erratic across those two factors and we know there were other differences among sites that altered $\mathrm{Hg}$ availability that were not quantified (e.g. habitat, water quality, soil composition, etc.). The model we tested included all the variables listed as base effects and also included interactions among site type and age, and site type and sex. We tested the interactions between sex, age and whether the site was a point source. We tested all possible interactions and used this model to evaluate our hypotheses. Instead of testing multiple models, we included variables into the model based on expert opinion then reported that model without removing individual terms with $p$ values greater 0.05 . While this method can lead to a model that has less predictive utility due to higher model error, this method is reasonable for testing specific hypotheses. The model presented here cannot be applied to predict $\mathrm{Hg}$ levels in bats outside of our study area.

For our second analysis we explored the relationship between blood-Hg and fur-Hg levels and the factors that influenced those relationships. We initially created a simple linear regression to look at overall correlation between blood and fur-Hg levels in adult and juvenile bats, but we also wanted to test how a variety of factors influenced the blood/fur relationship in a controlled modeling environmental. Specifically, we tested whether fur is an appropriate indicator of blood $\mathrm{Hg}$ for each captured species, both sexes, adults and juveniles, throughout the different reproductive stages of the breeding season (pregnant, lactating, etc.) and bats of a variety of sizes. To do this, we constructed another general linear mixed model with the primary objective being to determine the relationship between blood and fur-Hg levels in bats and how these factors might interact with this relationship. We used a subset of our total bat $\mathrm{Hg}$ database (those that have both blood and fur samples analyzed) so we could use a broader set of possible variables in this analyses without sacrificing sampling size. Even though there were only six sites used in this analysis, we included site as a random variable here to control for any unquantified site-specific effects. Like the first model, we developed a series of testable hypotheses a priori and included all in the final model regardless of significance where we can evaluate each relationship controlling for all other tested possibilities.

All $\mathrm{Hg}$ data was transformed using a natural logarithm to meet the normality requirements of the tests. All statistical analyses were performed using JMP 9.3 statistical program (SAS Institute 1985).

\section{Results}

A total of 2,128 tissue samples were collected and analyzed for $\mathrm{Hg}$, including 1,481 fur samples and 681 blood samples from 1,447 bats. Fur was collected from ten bat species and blood was collected from seven bat species. The mean fur total $\mathrm{Hg}$ concentration from the anthropogenic point source sites was $52.46 \mu \mathrm{g} / \mathrm{g} \quad(n=600$, range $0.38-707.64 \mu \mathrm{g} / \mathrm{g}$, $\mathrm{SD}=89.03)$, while at atmospheric de position sites the mean was $\quad 6.44 \mu \mathrm{g} / \mathrm{g} \quad(n=881, \quad$ range $\quad 0.07-120.31 \mu \mathrm{g} / \mathrm{g}$, $\mathrm{SD}=8.71)$. The blood total-Hg mean from point source sites was $0.47 \mu \mathrm{g} / \mathrm{g}(n=393$, range $0.002-3.76 \mu \mathrm{g} / \mathrm{g}, \mathrm{SD}=0.75)$ and the mean from the non-point sources was $0.05 \mu \mathrm{g} / \mathrm{g}$ ( $n=288$, range $0.002-0.55 \mu \mathrm{g} / \mathrm{g}, \mathrm{SD}=0.05$ ). The highest 
Table 1 Total $-\mathrm{Hg}$ concentrations in fur $(\mu \mathrm{g} / \mathrm{g}$, fw) and blood $(\mu \mathrm{g} / \mathrm{g}$, ww) by species in the Northeast U.S.

\begin{tabular}{|c|c|c|c|c|c|c|c|c|c|c|c|c|}
\hline \multirow[b]{2}{*}{ Species } & \multicolumn{6}{|c|}{ Total blood $\mathrm{Hg}$} & \multicolumn{6}{|c|}{ Total fur-Hg } \\
\hline & $n$ & Mean & $\begin{array}{l}25 \% \\
\text { quantile }\end{array}$ & Median & $\begin{array}{l}75 \% \\
\text { quantile }\end{array}$ & Max & $n$ & Mean & $\begin{array}{l}25 \% \\
\text { quantile }\end{array}$ & Median & $\begin{array}{l}75 \% \\
\text { quantile }\end{array}$ & $\operatorname{Max}$ \\
\hline Tri-colored & 75 & 40.77 & 4.92 & 15.30 & 52.21 & 255.00 & 29 & 0.74 & 0.12 & 0.42 & 1.09 & 2.75 \\
\hline Little brown & 851 & 29.22 & 2.49 & 5.39 & 15.69 & 707.64 & 410 & 0.28 & 0.02 & 0.04 & 0.18 & 3.76 \\
\hline Northern long-eared & 220 & 26.89 & 3.40 & 7.37 & 16.82 & 480.00 & 82 & 0.60 & 0.06 & 0.12 & 0.81 & 3.70 \\
\hline Gray & 7 & 18.61 & 2.70 & 5.37 & 24.80 & 84.50 & 7 & 0.12 & 0.01 & 0.02 & 0.24 & 0.46 \\
\hline Big brown & 203 & 16.64 & 4.59 & 9.59 & 18.10 & 200.00 & 127 & 0.10 & 0.04 & 0.06 & 0.11 & 0.89 \\
\hline Indiana & 12 & 10.58 & 6.17 & 10.35 & 16.04 & 18.30 & - & - & - & - & - & - \\
\hline Eastern small-footed & 7 & 12.88 & 7.54 & 15.70 & 16.50 & 18.83 & - & - & - & - & - & - \\
\hline Silver-haired & 6 & 7.96 & 5.15 & 7.89 & 10.17 & 14.23 & - & - & - & - & - & - \\
\hline Red & 54 & 4.03 & 1.29 & 2.73 & 5.22 & 25.54 & 20 & 0.05 & 0.01 & 0.03 & 0.06 & 0.22 \\
\hline Hoary & 12 & 1.33 & 0.66 & 1.34 & 1.71 & 3.61 & 6 & 0.02 & 0.01 & 0.01 & 0.03 & 0.03 \\
\hline
\end{tabular}

$\mathrm{Hg}$ means in fur and blood were detected in tri-colored (Perimyotis subflavus), little brown (Myotis lucifugus) and northern long-eared (Myotis septentrionalis) (Table 1).

Our first model showed good overall fit and suggests that species, age, sex and site contamination were all important to predicting fur-Hg levels (adj. $\left.\mathrm{r}^{2}=0.494\right)$. Controlling for site and year we found that there were significant differences among species fur-Hg levels $(\mathrm{F}(9,1155)=11.74$, $p<0.001)$. Myotis species-like eastern small-footed bat (Myotis leibii), Indiana bat (Myotis sodalis) and little-brown bat-tended to have the highest levels while migratory tree bats-like red (Lasiurus borealis), hoary (Lasiurus cinereus)and silver-haired bats (Lasionycteris noctivagans)-were the lowest (Fig. 2; Table 2). Site type, age and sex were tested together in all possible interactions and all were significant (Table 2). Adult females at contaminated sites had the highest average fur- $\mathrm{Hg}$ levels at $23.5 \pm 1.4 \mathrm{SE}$ $\mu \mathrm{g} / \mathrm{g}$ while adult males at such sites only averaged $13.4 \pm 1.4 \mathrm{SE} \mu \mathrm{g} / \mathrm{g}$. Juvenile males and females showed small differences at these sites also, females averaged $4.8 \pm 1.4 \mu \mathrm{g} / \mathrm{g}$ SE males averaged $6.4 \pm 1.4 \mu \mathrm{g} / \mathrm{g}$ SE. At uncontaminated sites, adults and juveniles showed differences (e.g. $5.2 \pm 1.7 \mathrm{SE} \mu \mathrm{g} / \mathrm{g}$ in adult females compared to $2.0 \pm 1.2 \mathrm{SE} \mu \mathrm{g} / \mathrm{g}$ in juvenile females). Year accounted for $2 \%$ of the total variance whereas site accounted for $17 \%$, suggesting differences among sites that we did not account for with our fixed effects. These data suggest that point source sites have a significant effect on Hg levels, in particular for adult Myotis females (though adult males and other species could also have high levels) (Fig. 3).

Without covariates, blood- $\mathrm{Hg}$ and fur- $\mathrm{Hg}$ levels were well-correlated overall (adult $\mathrm{r}^{2}=0.67, p<0.0001$, juvenile $r^{2}=0.87, p<0.0001 ;$ Fig. 4). Our model describing the blood-Hg/fur-Hg relationship fit well and showed significant relationships among all of the base variables we selected and good overall fit (adj. $\left.r^{2}=0.785\right)$.

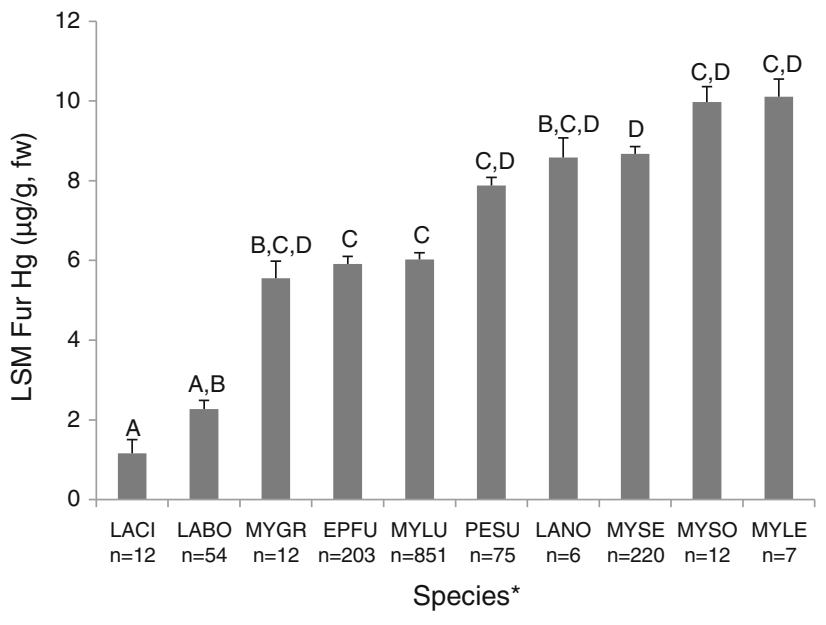

Fig. 2 Least square means of $\mathrm{Hg}(\mu \mathrm{g} / \mathrm{g}, \mathrm{w})$ in fur from bats separated by species with standard error bars. Letters within the mean bars represent the results of post hoc Tukey HSD test; bars that share common letters do not differ significantly. ${ }^{*} L A C I$ hoary, $L A B O$ red, $M Y G R$ gray, $E P F U$ big brown, $M Y L U$ little brown, $P E S U$ tri-colored, LANO silver-haired, MYSE northern long-eared, MYSO Indiana, $M Y L E$ eastern small-footed

Blood $\mathrm{Hg}$ was highly positively correlated with fur- $\mathrm{Hg}$ overall and was the most important single variable. With a beta value of $0.597 \pm 0.132$, fur is a good, positive predictor of blood $\mathrm{Hg}$ overall $(\mathrm{F}(1,658)=20.5, p<0.001)$, however our model has many possible interactions with this term and cannot be considered alone (Table 3). Species was highly important to the blood/fur relationship $(\mathrm{F}(6,658)=2.35, p=0.03)$. Tri-colored and red bats had lower blood levels than would be predicted by the average blood/fur relationship and gray bats had higher blood levels than predicted. Contaminated sites had much higher blood levels than would be predicted by average fur levels $(\mathrm{F}(1,644)=25.8 . p<0.001)$. Blood $\mathrm{Hg}$ levels changed with reproductive stage $(\mathrm{F}(3,660)=1.98, \quad p=0.117$; 
Table 2 Modeled effect size of fur-Hg levels across all factors in the top model

\begin{tabular}{lrcc}
\hline Modeling term & Estimate & S.E. & Prob $>t$ \\
\hline Intercept & 1.75 & 0.19 & $<0.0001$ \\
Sex [female] & 0.01 & 0.04 & 0.89 \\
Age [adult] & 0.52 & 0.04 & $<0.0001$ \\
Point source/non-point source [point & 0.54 & 0.15 & 0.00 \\
$\quad$ source] & & & \\
Tri-colored & 0.39 & 0.15 & 0.01 \\
Big brown & 0.04 & 0.12 & 0.73 \\
Red & -0.89 & 0.16 & $<0.0001$ \\
Hoary & -1.55 & 0.28 & $<0.0001$ \\
Silver-haired & 0.44 & 0.42 & 0.30 \\
Gray & -0.06 & 0.37 & 0.86 \\
Eastern small-footed & 0.58 & 0.38 & 0.12 \\
Little brown & 0.05 & 0.10 & 0.62 \\
Northern long-eared & 0.44 & 0.11 & 0.00 \\
Point source/non-point source $\times$ sex & 0.06 & 0.04 & 0.12 \\
Point source/non-point source $\times$ Age & 0.07 & 0.04 & 0.09 \\
Sex $\times$ age & 0.12 & 0.04 & 0.00 \\
Sex $\times$ age $\times$ contaminated/ & 0.09 & 0.04 & 0.01 \\
$\quad$ uncontaminated & & & \\
\hline C & & & \\
\hline
\end{tabular}

Categorical variables are relative to the unmentioned group (e.g., males for sex, juveniles for age, non-point source for point source presence and $M$. sodalis for species)

though see Table 4 for individual parameter estimates), non-reproductive bats had higher levels than all other stages, however there is also some evidence that the blood/ fur relationship varies also varies with reproductive stage $(\mathrm{F}(3,658)=2.16, p=0.09)$. Non-reproductive bats had a lower correlation between blood/fur levels. Sex, age and body mass had no effect on the blood/fur relationship.

\section{Percent MeHg in Fur}

$\mathrm{MeHg}$ was measured in fur from 20 bats captured at a nonpoint source site in Virginia to estimate the percent $\mathrm{MeHg}$ of total $\mathrm{Hg}$. MeHg ranged from 71 to $95 \%$ fur- $\mathrm{Hg}$ (mean $86 \%$ ). Five species were sampled, big brown (Eptesicus fuscus), red, little brown, northern long-eared and tri-colored, but sample sizes were too small to make a comparison among species (Table 5; Fig. 5). The trend of higher total $\mathrm{Hg}$ and $\mathrm{MeHg}$ exhibited a strong positive correlation and showed that when $\mathrm{THg}$ increased $\mathrm{MeHg}$ increased at a similar rate almost a 1:1 ratio $\left(\mathrm{r}^{2}=99, \mathrm{~F}=22304.22, p<0.001\right)$.

\section{Discussion}

Bats captured at point sources in the northeastern US had significantly higher mean $\mathrm{Hg}$ concentrations in fur and
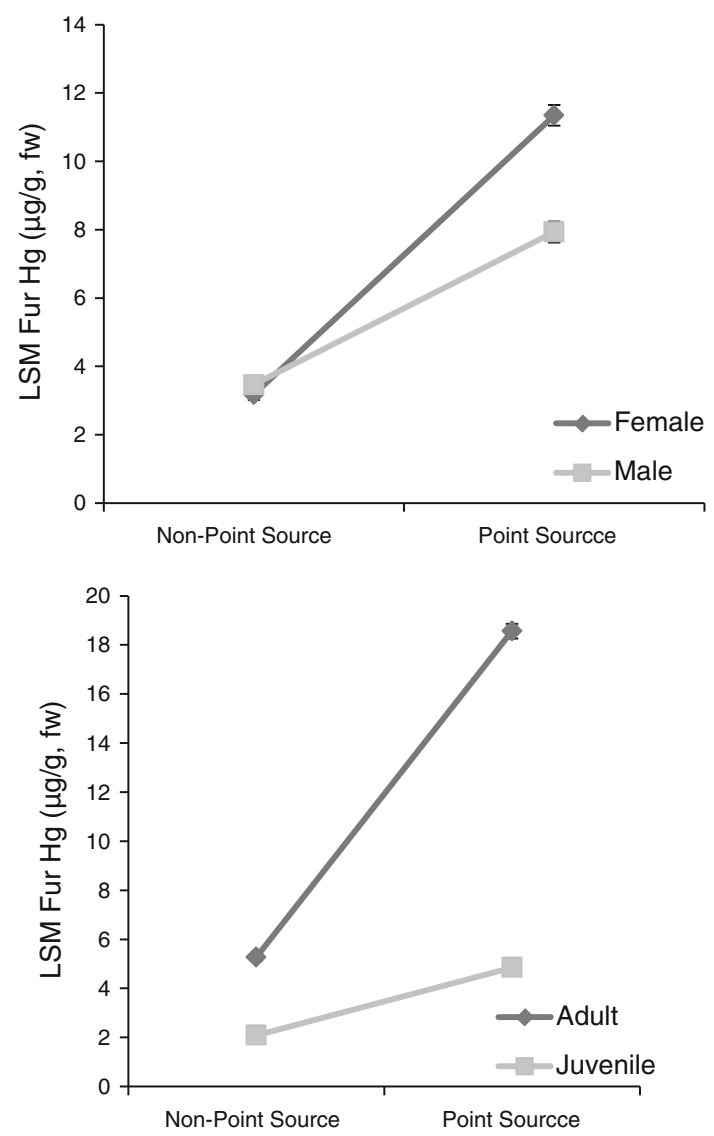

Fig. 3 Least square means of $\mathrm{Hg}(\mu \mathrm{g} / \mathrm{g}, \mathrm{w})$ in fur showing sex and age at point source and non-point source sites with standard error bars

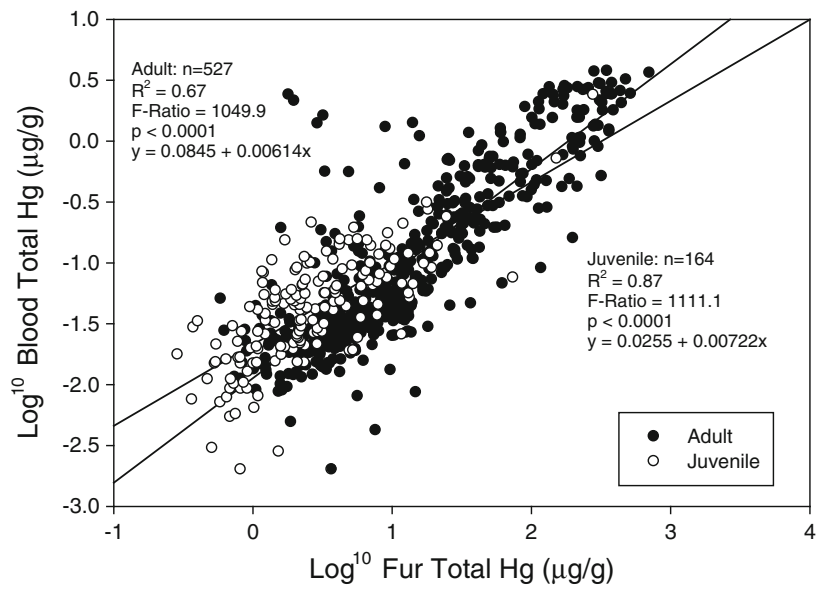

Fig. 4 Correlations between concentration of $\mathrm{Hg}$ in blood and fur from juvenile and adult bats

blood compared to those from non-point source $\mathrm{Hg}$ sites. When all species and age classes were combined, the mean concentrations of $\mathrm{Hg}$ in fur from the combined anthropogenic point sources $(52.7 \mu \mathrm{g} / \mathrm{g}$, fw $)$ were almost eight times higher than from non-point sources $(6.7 \mu \mathrm{g} / \mathrm{g}, \mathrm{fw})$. The 
Table 3 Modeled effect size of fur-Hg levels across all factors in the top model

\begin{tabular}{lccc}
\hline Modeling term & F-ratio & DF & Prob $>F$ \\
\hline Contaminated/uncontaminated & 2.46 & 1 & 0.17 \\
Species & 7.01 & 6 & $<0.0001$ \\
Sex & 0.58 & 1 & 0.45 \\
Age & 0.04 & 1 & 0.84 \\
Body mass & 2.23 & 1 & 0.14 \\
Forearm length & 0.10 & 1 & 0.75 \\
Reproductive status & 1.97 & 3 & 0.12 \\
Fur mercury level & 20.52 & 1 & $<0.0001$ \\
Fur mercury $\times$ contaminated/ & 25.82 & 1 & $<0.0001$ \\
$\quad$ uncontaminated & & & \\
Fur mercury $\times$ species & 2.35 & 6 & 0.03 \\
Fur mercury $\times$ sex & 0.20 & 1 & 0.66 \\
Fur mercury $\times$ age & 0.11 & 1 & 0.74 \\
Fur mercury $\times$ body mass & 1.29 & 1 & 0.26 \\
Fur mercury $\times$ reproductive status & 2.16 & 3 & 0.09 \\
\hline
\end{tabular}

Categorical variables are relative to the unmentioned group (e.g. males for sex, juveniles for age, non-point source for point source presence and $M$. sodalis for species)

mean concentration of $\mathrm{Hg}$ in blood found at the combined point sources $(0.47 \mu \mathrm{g} / \mathrm{g}$, ww $)$ was ten times higher than the mean of non-point sources $(0.047 \mu \mathrm{g} / \mathrm{g}$, ww $)$. Other researchers have reported the concentrations of $\mathrm{Hg}$ in bats (Baron et al. 1999; Brooks and Ford 2005; Hickey et al. 2001; Miura et al. 1978; O'Shea et al. 2001; Petit and Altenbach 1973; Powell 1983; Wada et al. 2010; Walker et al. 2007), however, the present study provides the largest dataset on $\mathrm{Hg}$ concentrations in fur and blood from bats to date.

Blood total $\mathrm{Hg}$ concentrations generally represents recent dietary uptake of $\mathrm{MeHg}$; fur- $\mathrm{Hg}$ concentrations indicates $\mathrm{Hg}$ at the time of fur growth in which the $\mathrm{Hg}$ is remobilized by muscle and organs and sequestered in growing fur (Evers et al. 2005; Mierle et al. 2000; Yates et al. 2005). Concentrations of $\mathrm{Hg}$ in fur is an expression of chronic exposure (Mierle et al. 2000), the total Hg concentrations in the fur of juveniles were lower than in adults which indicates accumulation over time. This could explain the significant difference in $\mathrm{Hg}$ concentrations in the fur of adult and juvenile bats from the point sources. When comparing point source and non-point source sites, only juvenile little browns differed significantly in mean concentrations of $\mathrm{Hg}$ in fur and blood. Adults of all species differed significantly between point and non-point source sites except for red (fur and blood $\mathrm{Hg}$ ), hoary (fur-Hg) and tri-colored bats (blood $\mathrm{Hg}$ ). Body weight and $\mathrm{Hg}$ concentrations were negatively correlated in bats from point source sites, which suggest that bats maybe able to
Table 4 Modeled effect size of fur-Hg levels across all factors in the top model

\begin{tabular}{|c|c|c|c|}
\hline Modeling term & Estimate & S.E. & Prob $>t$ \\
\hline Intercept & -0.92 & 0.99 & $<0.0001$ \\
\hline $\begin{array}{l}\text { Contaminated/uncontaminated } \\
\text { [contaminated] }\end{array}$ & -0.24 & 0.15 & 0.17 \\
\hline Tri-colored & 1.89 & 0.39 & $<0.0001$ \\
\hline Big brown & -0.23 & 0.32 & 0.48 \\
\hline Red & -0.14 & 0.23 & 0.54 \\
\hline Hoary & -1.03 & 0.64 & 0.11 \\
\hline Gray & -1.00 & 0.42 & 0.02 \\
\hline Little brown & 0.03 & 0.27 & 0.90 \\
\hline Sex [female] & 0.06 & 0.08 & 0.45 \\
\hline Age [adult] & -0.02 & 0.09 & 0.84 \\
\hline Body mass & 0.07 & 0.05 & 0.14 \\
\hline Forearm length & 0.01 & 0.02 & 0.75 \\
\hline Reproductive status [lactating] & -0.11 & 0.12 & 0.37 \\
\hline Reproductive status [not reproductive] & 0.31 & 0.14 & 0.03 \\
\hline Reproductive status [pregnant] & -0.13 & 0.24 & 0.58 \\
\hline Fur mercury level & 0.60 & 0.13 & $<0.0001$ \\
\hline $\begin{array}{l}\text { Fur mercury level } \times \text { contaminated/ } \\
\text { uncontaminated [contaminated] }\end{array}$ & 0.16 & 0.03 & $<0.0001$ \\
\hline Fur mercury level $\times$ tri-colored & -0.30 & 0.17 & 0.08 \\
\hline Fur mercury level $\times$ big brown & -0.04 & 0.17 & 0.80 \\
\hline Fur mercury level $\times$ red & -0.25 & 0.18 & 0.16 \\
\hline Fur mercury level $\times$ hoary & 0.36 & 0.69 & 0.60 \\
\hline Fur mercury level $\times$ gray & 0.26 & 0.20 & 0.20 \\
\hline Fur mercury level $\times$ little brown & 0.00 & 0.15 & 0.99 \\
\hline Fur mercury level $\times$ sex [female] & 0.01 & 0.03 & 0.66 \\
\hline Fur mercury level $\times$ age [adult] & 0.01 & 0.04 & 0.74 \\
\hline Fur mercury level $\times$ body mass & -0.02 & 0.02 & 0.26 \\
\hline $\begin{array}{l}\text { Fur mercury level } \times \text { reproductive status } \\
\text { [lactating] }\end{array}$ & 0.05 & 0.04 & 0.22 \\
\hline $\begin{array}{l}\text { Fur mercury level } \times \text { reproductive status } \\
\text { [not reproductive] }\end{array}$ & -0.08 & 0.05 & 0.08 \\
\hline $\begin{array}{l}\text { Fur mercury level } \times \text { reproductive status } \\
\text { [pregnant] }\end{array}$ & 0.07 & 0.09 & 0.42 \\
\hline
\end{tabular}

Categorical variables are relative to the unmentioned group (e.g. males for sex, juveniles for age, non-point source for point source presence, post-lactating for reproductive status and M. sodalis for species)

depurate $\mathrm{Hg}$ more efficiently through excreting it in the keratin in their fur (Wada et al. 2010). Conversely, if larger bats have lower fur-Hg it could be due in part to a dilution effect where the larger body diluting the contaminant or that the bat is feeding at a lower trophic position on the insects that are not accumulating as much $\mathrm{Hg}$.

Bats accumulate the majority of $\mathrm{Hg}$ through their diet of emergent insects, using both aerial and gleaning foraging techniques over river surfaces and floodplain edges (Baron et al. 1999). The difference in means for fur and blood $-\mathrm{Hg}$ between species within a site is likely due to differing 
Table 5 Mean $( \pm$ SD) total $\mathrm{Hg}(\mu \mathrm{g} / \mathrm{g}, \mathrm{fw}), \mathrm{MeHg}(\mu \mathrm{g} / \mathrm{g}, \mathrm{fw})$ and $\mathrm{MeHg}$ percentages from bat fur separated by species

\begin{tabular}{lcccl}
\hline Species & $N$ & Mean total Hg & Mean MeHg & $\begin{array}{l}\text { Mean } \\
\text { MeHg }(\%)\end{array}$ \\
\hline Big brown & 5 & $9.89( \pm 9.44)$ & $8.61( \pm 8.54)$ & $85( \pm 2 \%)$ \\
Red & 3 & $3.76( \pm 1.21)$ & $3.15( \pm 1.03)$ & $84( \pm 1 \%)$ \\
Little brown & 4 & $18.89( \pm 13.17)$ & $16.43( \pm 11.60)$ & $86( \pm 2 \%)$ \\
$\begin{array}{l}\text { Northern } \\
\quad \text { long-eared }\end{array}$ & 6 & $7.11( \pm 9.35)$ & $6.19( \pm 8.20)$ & $85( \pm 6 \%)$ \\
Tri-colored & 2 & $7.97( \pm 0.56)$ & $7.45( \pm 0.66)$ & $93( \pm 2 \%)$ \\
\hline
\end{tabular}

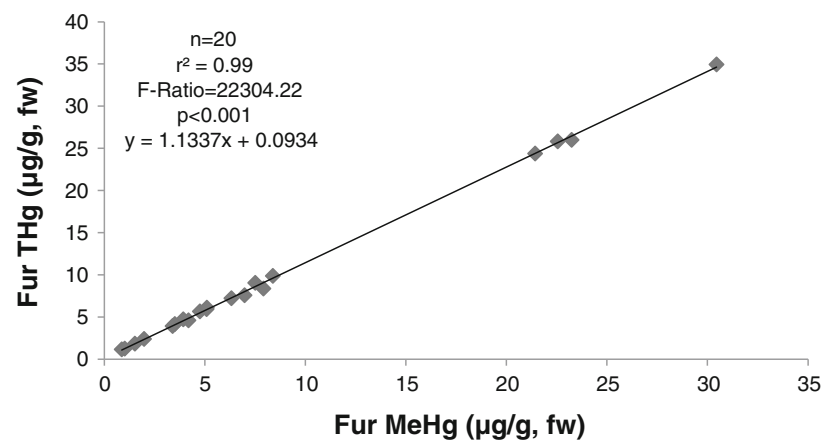

Fig. 5 Correlation between total $\mathrm{Hg}$ and $\mathrm{MeHg}$ in adult bats

feeding strategies and prey choice. A 2003 dietary study of bats showed that common prey items of big brown, little brown and tri-colored bats had varied diets, and includes Coleoptera, Hemiptera, Lepidoptera, Homoptera, Diptera, Hymenoptera and Trichoptera. Diets for these bats did not differ from diets in other regions of the United States (Carter et al. 2003). In New Hampshire, the diet of little brown bats includes insect orders Diptera, Hemiptera, Trichoptera, Lepidoptera, Coleoptera, and Arachnida (Anthony and Kunz 1977). In Maryland and Pennsylvania, big brown bat has a varied diet, but predominately feeds on Coleoptera (Agosta and Morton, 2003). In Ontario, red bats also have a varied diet, consuming over 127 different species of insects, and represent eight orders (Clare et al. 2009). Hoary bats consume prey similar to big brown, little brown and tri-colored while migrating through New Mexico, with the exception of Trichoptera (Valdez and Cryan 2009). Carter et al. (2003) found that northern longeared and red bats also prey upon Coleoptera and Lepidoptera. Other studies found that the main prey of northern long-eared bat was Coleoptera and Lepidoptera, but overall had a varied diet, including arachnids (Brack and Whitaker 2001; Whitaker and Hamilton 1998). Similar to little brown and tri-colored, Indiana bats have a varied diet in Missouri and Indiana including: Lepidoptera, Coleoptera, Trichoptera, and Diptera. Spiders and Lepidoptera larva were also found in the stomachs of this species from a cave in Indiana (Brack and Whitaker 2001). Arachnids had higher Hg concentrations than other terrestrial invertebrates collected at the South River, Virginia (Cristol et al. 2008) and could explain why Myotis sp. had some of the highest levels of $\mathrm{Hg}$ in this study. Red and hoary bats consistently had the lowest mean concentrations of $\mathrm{Hg}$ in fur and blood when compared to other species included in our study. In addition to prey preferences and migratory behavior may also result in lower concentrations of $\mathrm{Hg}$ in blood and fur in species of Lasiurus. Given that species of Lasiurus examined in the present study are highly territorial, they are not likely to forage over the same point source rivers for extended periods of time and some of the bats captured may have been new to the area where they were sampled, explaining their lower fur and blood $\mathrm{Hg}$ concentrations.

Differences between male and female bats were detected in mean concentration of total $\mathrm{Hg}$ in fur and blood from both point source and non-point source sites. We hypothesize that female bats exhibited higher $\mathrm{Hg}$ concentrations than males at point source site due to decreased foraging distances (thus closer proximity to the point source) during pup rearing. This can also partially explain why female bats at point source sites had significantly higher $\mathrm{Hg}$ than female bats at non-point source sites. Since females depurate $\mathrm{Hg}$ through birth and milk production it was thought that they may have lower total $\mathrm{Hg}$ burdens but this was not the case in this study. This finding could have larger implications since reproducing females are more susceptible to accumulating $\mathrm{Hg}$. Mercury is readily transferred across the placenta, and concentrates selectively in the fetal brain. Yang et al. (1972) found $\mathrm{Hg}$ concentrations in the fetal brain of rodents fed $\mathrm{MeHg}$ were twice as high as in the maternal brain. Reproductive effects of $\mathrm{MeHg}$ in mammals range from developmental alterations in the fetus, which produce behavioral or physical deficits after birth, to death (Chang et al. 1974; Chang and Annau 1984; Eccles and Annau 1987; Khera 1979; Wren et al. 1987). These effects could lead to a decrease in bat reproductive success, especially considering the reported high female $\mathrm{Hg}$ levels.

Procella et al. (2004) found that $\mathrm{MeHg}$ ratios were highest in the fur of raccoons ( $99 \%$ of $\mathrm{THg}$ ) compared to blood, brain, heart, kidney, liver and muscle samples. In otter and mink, percentages in fur were 79 and $65 \%$, respectively, and were not the highest in fur when compared to brain, kidney and liver sample (Evans et al. 2000). We found that $\mathrm{MeHg}$ in the fur of bats sampled fell within a similar range of 71-95\%. Concentrations of $\mathrm{MeHg}$ in human hair and bat fur are highly correlated with concentrations in blood (Clarkson and Magos 2006).

Based on $\mathrm{Hg}$ exposure profiles for bats in 2006-09 in the present study, there is compelling evidence of $\mathrm{Hg}$ at point source and some non-point sources having the potential to have an adverse affect on insectivorous bats. Dong-Ha Nam et al. (2012) found bats had $\mathrm{Hg}$-associated neurochemical 
changes with range of $10-40 \mu \mathrm{g}$ total $\mathrm{Hg} / \mathrm{g}$, fw, threshold in fur. Sixty-nine percent of the $\mathrm{Hg}$ levels in fur of adult bats that we analyzed from point sources exceed $10 \mu \mathrm{g} / \mathrm{g}$, fw, whereas only $21 \%$ of the adult bats have Hg levels in fur from the non-point sources are above the $10 \mu \mathrm{g} / \mathrm{g}$, fw threshold. Other small mammals including mice have similar neurochemical affects from being exposed to $\mathrm{Hg}$. Burton et al. (1977) found that wild mice, eating brine flies from the Great Salt Lake, had $\mathrm{Hg}$ concentrations over $7.8 \mu \mathrm{g} / \mathrm{g}$, fw in fur exhibited behavioral deviations and had a decrease in ambulatory activity when compared to a control group. Burton et al. (1977) also found that mice with $\mathrm{Hg}$ concentrations in fur of $10.8 \mu \mathrm{g} / \mathrm{g}$, fw showed decreased stress tolerance and decreased swimming ability. Eightyone percent and $32 \%$ of the adult bats from the point and non-point sources had $\mathrm{Hg}$ concentration that exceeded the effect level of $7.8 \mu \mathrm{g} / \mathrm{g}$, fw, respectively.

Bats are increasingly of high conservation concern owing to the impacts of various anthropogenic influences (Jones et al. 2009). Mercury is an anthropogenic stressor on bats that may be compounded by other stressors such as white-nose syndrome, a syndrome that has been causing mass mortality among hibernating bats throughout the Northeast and MidAtlantic states (Frick et al. 2010). Thus, future investigations are important to determine spatially and temporally explicit effects from $\mathrm{Hg}$ with high resolution of reproductive success, survival, and physiological responses to emerging pathogens and other stressors or contaminants are of considerable importance to bat conservation. More studies examining the effects of $\mathrm{Hg}$ on bats are needed to quantify if bats are being affected by these elevated $\mathrm{Hg}$ concentrations. Two of the bats sampled [Indiana and gray (Myotis grisescens)] in the study are already protected by the Endangered Species Act (ESA 1973) and two more are pending (eastern small-footed, northern long-eared) with possibly a third under consideration in the near future (little brown). All had elevated $\mathrm{Hg}$ concentrations which may be of concern. Bats provide important ecosystem services and are a keystone species (Boyles et al. 2011; Kunz et al. 2011), and their protection must be made a high priority.

Acknowledgments We would like to thank The Nature Conservancy, DuPont ${ }^{\mathrm{TM}}$, USF\&W, NYSERDA, Olin Corporation and the National Science Foundation for financial support. We are grateful to the Augusta Forestry Center, VA, and the Rankin, Heding and Craig families for providing access to their properties. We would also like to thank the many biologists that helped obtain samples for this study Lucas Savoy, Dustin Meatty, Pedro Ardapple, Casey Huck, Patrick Keenan, John Chenger, Craig Stihler (WVDNR), Rick Reynolds (VADGF), Alan Hicks, Aimee Haskew and all the field technicians that put in countless hours. Jeffery Tash for the GIS map provided and David Buck for review of final manuscript. Sniegole Stapcinskaite from UConn for her work in the analysis of tissue samples for $\mathrm{Hg}$. Also thanks to the two anonymous reviewers that provided valuable comments on an earlier draft. The findings and conclusions in this article are those of the author(s) and do not necessarily represent the views of the U.S. Fish and Wildlife Service.

Conflict of interest The authors declare that they have no conflict of interest.

Open Access This article is distributed under the terms of the Creative Commons Attribution License which permits any use, distribution, and reproduction in any medium, provided the original author(s) and the source are credited.

\section{References}

Agosta SJ, Morton D (2003) Diet of the big brown bat, Eptesicus fuscus, from Pennsylvania and western Maryland. Northeast Nat 10(1):89-104

Anthony ELP, Kunz TH (1977) Feeding strategies of the little brown bat, Myotis lucifugus, in southern New Hampshire. Ecology 58:775-786

Barclay RMR, Harder LD (2003) Life histories of bats: life in the slow lane. In: Kunz TH, Fenton MB (eds) Bat ecology. The University of Chicago Press, Chicago, pp 209-253

Baron LA, Sample BE, Suter GW (1999) Ecological risk assessment in a large river-reservoir: 5. Aerial insectivorous wildlife. Environ Toxicol Chem 18(4):621-627

Boyles JG, Cryan PM, McCracken GF, Kunz TH (2011) Economic importance of bats in agriculture. Science 332:41-42

Brack VJ, Whitaker JO (2001) Foods of the northern myotis, Myotis septentrionalis, from Missouri and Indiana, with notes on foraging. Acta Chiropterologica 3(2):203-210

Brooks RT, Ford WM (2005) Bat activity in a forest landscape of central Massachusetts. Northeast Nat 12:447-462

Brunet-Rossini A (2004) Reduced free-radical production and extreme longevity in the little brown bat (Myotis lucifugus) versus two non-flying mammals. Mech Aging Dev 125:11-20

Brunet-Rossini A, Austed S (2004) Ageing studies on bats: a review. Biogerontology 5:211-222

Burton GV, Alley RJ, Rasmussen GL, Orton P, Cox V, Jones P, Graff D (1977) Mercury and behavior in wild mouse populations. Environ Res 14(1):30-34

Carter TC, Menze IMA, Owen SF, Edwards JW, V JM, Ford WM (2003) Food habits of seven species of bats in the Allegheny Plateau and Ridge and Valley of West Virginia. Northeast Nat 10(1):83-88

Chang LW, Annau Z (1984) Developmental neuropathology and behavioral teratology of methylmercury. In: Yanai J (ed) Neurobehavioral teratology. Elsevier, Amsterdam, pp 405-432

Chang LW, Yamachghi S, Dudley AWJ (1974) Neurological changes in cats following long-term diet of mercury contaminated tuna. Acta Neuropathol (Berl) 27:171-176

Chasar LC, Scudder BC, Stewart AR, Bell AH, Aiken GR (2009) Mercury cycling in stream ecosystems. 3. Trophic dynamics and methylmercury bioaccumulation. Environ Sci Technol 43: 2733-2739

Chen CY, Stemberger RS, Kamman NC, Mayes BM, Folt CL (2005) Patterns of $\mathrm{Hg}$ bioaccumulation and transfer in aquatic food webs across multi-lake studies in the northeast US. Ecotoxicology 14:135-147

Clare EL, Fraser EE, Braid HE, Fenton MB, Herbert PDN (2009) Species on the menu of a generalist predator, the eastern red bat (Lasiurus borealis): using a molecular approach to detect arthropod prey. Mol Ecol 18:2532-2542 
Clarkson TW, Magos L (2006) The toxicology of mercury and its chemical compounds. Crit Rev Toxicol 36:609-662

Constantine DG (1958) An automatic bat-collecting device. J Wildl Manag 22(1):17-22

Cristol DA, Brasso RL, Condon AM, Fovargue RE, Friedman SL, Hallinger KK, Monroe AP, White AE (2008) The movement of aquatic mercury through terrestrial food webs. Science 320:335

Driscoll CT, Han Y-J, Chen CY, Evers DC, Lambert KF, Holsen TM, Kamman NC, Munson RK (2007) Mercury contamination in forest and freshwater ecosystems in the northeastern United States. Bioscience 57:17-28

Eccles CU, Annau Z (1987) Prenatal exposure to methylmercury. In: Eccles CU, Annau Z (eds) The toxicity of methylmercury. Johns Hopkins University Press, Baltimore, pp 114-130

Edmonds ST, Evers DC, Cristol DA, Mettke-Hofmann C, Powell LL, McGann AJ, Armiger JW, Lane OP, Tessler DF, Newell P, Heyden K, O’Driscoll NJ (2010) Geographic and seasonal variation in mercury exposure of the declining rusty blackbird. Condor 112(4):789-799

Evans RD, Addison EM, Villeneuve JY, MacDonald KS, Joachim DC (2000) Distribution of inorganic and methylmercury among tissues in mink (Mustela vison) and otter (Lutra canadensis). Environ Res Sect A 84:133-139

Evers DC, Clair TA (2005) Mercury in northeastern North America: a synthesis of existing databases. Ecotoxicology 14:7-14

Evers DC, Burgess NM, Champoux L, Hoskins B, Major A, Goodale MW, Taylor RJ, Poppenga R, Daigle T (2005) Patterns and interpretation of mercury exposure in freshwater avian communities in northeastern North America. Ecotoxicology 14:193-221

Evers DC, Han Y-J, Driscoll CT, Kamman NC, Goodale MW, Lambert KF, Holsen TM, Chen CY, Clair TA, Butler T (2007) Biological mercury hotspots in the northeastern United States and southeastern Canada. Bioscience 57:29-43

Frick WF, Pollock JF, Hicks A, Langwig K, Reynolds DS, Turner G, Butchowski C, Kunz TH (2010) An emerging disease causes regional population collapse of a common North American bat species. Science 329:679-682

Grippo RS, Massa SA (2000) Mercury levels in Arkansas bats from counties under advisories for fish consumption. Thesis, Arkansas State University

Hickey MBC, Fenton MB, MacDonald KC, Soulliere C (2001) Trace elements in the fur of bats (Chiroptera: Vespertilionidae) from Ontario and Quebec, Canada. Bull Environ Contam Toxicol 66:669-706

Institute SAS (1985) SAS/STAT guide for personal computers version 6 edn. SAS Institute, Cary 1028

Jones G, Jacobs DS, Kunz TH, Willig MR, Racey PA (2009) Carpe noctem: the importance of bats as bioindicators. Endanger Species Res 8:93-115

Khera KS (1979) Teratogenic and genetic effects of mercury toxicity. In: Nriagu JO (ed) The biogeochemistry of mercury in the environment. Elsevier/North-Holland, Amsterdam, pp 503-518

Kunz T (2004) Foraging habits of North American insectivorous bats. In: Brigham R, Kalko EKV, Jones G, Parsons S, Limpens HJGA (eds) Bat echolocation research: tool, techniques, and analysis. Bat Conservation International, Austin, pp 13-25

Kunz TH, Anthony EL (1982) Age estimation and post-natal growth in the bat Myotis lucifugus. J Mammal 63(1):23-32

Kunz TH, Lumsden LF (2003) Ecology of cavity and foliage roosting bats. In: Kunz TH, Fenton MB (eds) Bat ecology. University of Chicago Press, Chicago, pp 3-89

Kunz TH, Whitaker JO, Wadanoli MD (1995) Dietary energetics of the insectivorous Mexican free-tailed bat (Tadarida brasiliensis) during pregnancy and lactation. Oecologia 101:407-415

Kunz TH, Braun de Torrez E, Bauer DM, Lobova TA, Fleming TH (2011) Ecosystem services provided by bats. In: Ostfeld RA,
Schlesinger WH (eds) The year in ecology and conservation. Annals of the New York Academy of Sciences, Wiley-Blackwell, New York, pp 1-38

Kurta A, Bell GP, Nagy KA, Kunz TH (1989) Energetics of pregnancy and lactation in free-ranging little brown bats (Myotis lucifugus). Physiol Zool 62:804-818

Lesnik B, Fordham O, USEPA (1998) An update of the current status of the RCRA methods development program, 4BLWP804

Liang L, Horvat M, Bloom NS (1994) An improved speciation method for mercury by GC/CVAFS after aqueous phase ethylation and room temperature precollection. Talanta 41(3):371-379

Mickleburgh SP, Hutson AM, Racey PA (2002) A review of the global conservation status of bats. Oryx 36:18-34

Mierle G, Addison EM, MacDonald KS, Joachim DG (2000) Mercury levels in tissues of otters from Ontario, Canada: variation with age, sex, and location. Environ Toxicol Chem 19:3044-3051

Miura T, Koyama T, Nakamura I (1978) Mercury content in museum and recent specimens of chiroptera in Japan. Bull Environ Contam Toxicol 20:696-701

Nam D-H, Yates D, Ardapple P, Evers DC, Schmerfeld J, Basu N (2012) Elevated mercury exposure and neurochemical alterations in little brown bats (Myotis lucifugus) from a site with historical mercury contamination. Ecotoxicology 21(4):1094-1101

O'Shea TJ, Johnson JJ (2009) Environmental contaminants and bats: Investigating exposure and effects. In: Kunz TH, Parsons S (eds) Ecological and behavioral methods for the study of bats. Johns Hopkins University Press, Baltimore, pp 500-528

O'Shea TJ, Everette AL, Ellison LE (2001) Cyclodiene insecticide, DDE, DDT, arsenic, and mercury contamination of big brown bats (Eptesicus fuscus) foraging at a Colorado superfund site. Arch Environ Contam Toxicol 40:112-120

Petit MG, Altenbach JS (1973) A chronological record of environmental chemicals from analysis of stratified vertebrate excretion deposited in a shelter environment. Environ Res 6:339-343

Pirrone N, Cinnirella S, Feng X, Finkelman RB, Friedli HR, Leaner J, Mason R, Mukherjee AB, Stracher GB, Streets DG, Telmer K (2010) Global mercury emissions to the atmosphere from anthropogenic and natural sources. Atmos Chem Phys $10: 5951-5964 \mathrm{v}$

Powell GVN (1983) Industrial effluent as a source of mercury contamination in terrestrial riparian vertebrates. Environ Pollut 5:51-57

Procella DB, Zillioux EJ, Grieb TM, Newman JR, West GB (2004) Retrospective study of mercury in raccoons (Procyon lotor) in south Florida. Ecotoxicology 13:207-221

Schuster PF, Krabbenhoft DP, Naftz DL, Cecil LD, Olson ML, Dewild JF, Susong DD, Green JR, Abbott ML (2002) Atmospheric mercury deposition during the last 270 years: a glacial ice core record of natural and anthropogenic sources. Environ Sci Technol 36(11):2303-2310

U.S. Environmental Protection Agency (2010) Waste and cleanup risk assessment glossary: U.S. Environmental Protection Agency. Access date 1 July 2011

USFWS (2010) Disinfection protocol for bat field studies, region 3. http://www.fwsgov/midwest/endangered/mammals/BatDisinfect ionProtocol.html

Valdez EW, Cryan PM (2009) Food habits of the hoary bat (Lasiurus cinereus) during spring migration through New Mexico. Southwest Nat 54:195-200

Wada H, Yates DE, Evers DC, Taylor RJ, Hopkins WA (2010) Tissue mercury concentrations and adrenocortical responses of female big brown bats (Eptesicus fuscus) near a contaminated river. Ecotoxicology 19:1277-1284

Walker LA, Simpson VR, Rockett L, Wienberg CL, Shore RF (2007) Heavy metal contamination in bats in Britain. Environ Pollut 148:483-490 
Ward DM, Nislow KH, Folt CL (2010) Bioaccumulation syndrome: identifying factors that make some stream food webs prone to elevated mercury bioaccumulation. Ann N Y Acad Sci 1195:62-83

Whitaker JO, Hamilton WJ (1998) Order chiroptera: bats. In: Mammals of the eastern United States 3rd edn. Cornell University Press, Ithaca, pp 73-156

Wilkinson G, South J (2002) Life history, ecology and longevity in bats. Aging Cell 1:124-131

Wren CD, Hunter DB, Leatherland JF, Stokes PM (1987) The effects of polychlorinated biphenyls and methylmercury, singly and in combination, on mink. I: uptake and toxic responses. Arch Environ Contam Toxicol 16:441-447

Yang MG, Krawford KS, Gareia JD, Wang JHC, Lei KY (1972) Deposition of mercury in fetal and maternal brain. Proc Soc Exp Biol Med 141:1004-1007

Yates DE, Mayack DT, Munney K, Evers DC, Major A, Kaur T, Taylor RJ (2005) Mercury levels in mink (Mustela vison) and river otter (Lontra canadensis) from northeastern North America. Ecotoxicology 14:263-274 